\title{
Correction to: Holocrine secretion and kino flow in angiosperms: their role and physiological advantages in plant defence mechanisms
}

\author{
Paulo Cabrita ${ }^{1,2}$ (D)
}

Published online: 23 July 2021

(c) The Author(s) 2021

\section{Correction to: Trees (2020) 34:1183-1204 https://doi.org/10.1007/s00468-020-01990-z}

The article "Holocrine secretion and kino flow in angiosperms: their role and physiological advantages in plant defence mechanisms", written by Paulo Cabrita, was originally published electronically on the publisher's internet portal on 25 May 2020 without open access. With the author(s)' decision to opt for Open Choice, the copyright of the article changed on 2nd July 2021 to () The Author(s) 2021 and the article is forthwith distributed under a Creative Commons Attribution 4.0 International License, which permits use, sharing, adaptation, distribution and reproduction in any medium or format, as long as you give appropriate credit to the original author(s) and the source, provide a link to the Creative Commons licence, and indicate if changes were made. The images or other third party material in this article is included in the article's Creative Commons licence, unless indicated otherwise in a credit line to the material. If material is not included in the article's Creative Commons licence and your intended use is not permitted by statutory regulation or exceeds the permitted use, you will need to obtain permission directly from the copyright holder. To view a copy of this licence, visit http://creativecommons. org/licenses/by/4.0. Open access funding enabled and organized by Projekt DEAL.

The original article has been corrected.

Open Access This article is licensed under a Creative Commons Attribution 4.0 International License, which permits use, sharing, adaptation, distribution and reproduction in any medium or format, as long as you give appropriate credit to the original author(s) and the source, provide a link to the Creative Commons licence, and indicate if changes were made. The images or other third party material in this article are included in the article's Creative Commons licence, unless indicated otherwise in a credit line to the material. If material is not included in the article's Creative Commons licence and your intended use is not permitted by statutory regulation or exceeds the permitted use, you will need to obtain permission directly from the copyright holder. To view a copy of this licence, visit http://creativecommons.org/licenses/by/4.0/.

Publisher's Note Springer Nature remains neutral with regard to jurisdictional claims in published maps and institutional affiliations.
The original article can be found online at https://doi.org/10.1007/

s00468-020-01990-z.

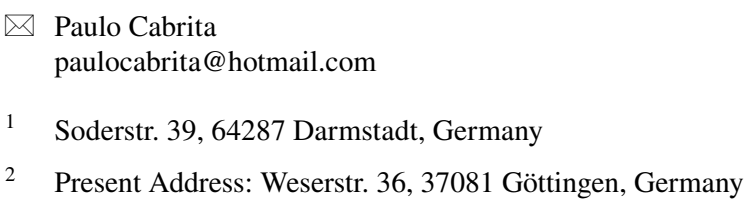

\begin{tabular}{ll}
\hline & $\begin{array}{l}\text { Paulo Cabrita } \\
\text { paulocabrita@ hotmail.com }\end{array}$ \\
1 & Soderstr. 39, 64287 Darmstadt, Germany \\
2 & Present Address: Weserstr. 36, 37081 Göttingen, Germany
\end{tabular}

